\title{
The Effects of Focused/Unfocused Audio-Appended Reading Tasks on Intermediate Female EFL Learners' Written Accuracy
}

\section{Parviz Alavinia}

Dr., corresponding author, English Language Department, Urmia University, Urmia, Iran,pevinia2006@yahoo.com

\author{
Ali Shafaei \\ $\mathrm{PhD}$ Candidate in TEFL, English Language Department, Urmia University, Urmia, Iran, \\ shafaeiali64@gmail.com
}

\author{
Asghar Salimi \\ Dr., English Language Department, University of Maragheh, Maragheh, Iran, \\ asgharsalimi356@gmail.com
}

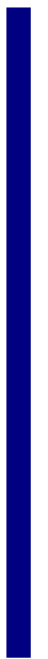

The current research study was conducted to examine the impacts of focused and unfocused audio-appended reading tasks on female EFL learners' acquisition of a rule-bound structure (passive voice) and a non-rule-bound structure (prepositions). The participants of this study involved ninety intermediate female English learners. They were assigned into four experimental and two control groups on the basis of the instruction they were exposed to. The learners were instructed for ten sessions via focused and unfocused reading tasks. In the last session, the posttest of the study which included a rendering task was administered among the learners to measure their grammatical development. The results of the current research revealed significant differences between the performances of focused and unfocused groups in terms of the production element of accuracy in both rulebound and non-rule-bound structures. The results of the current research showed that the learners who were exposed to focused audio-appended reading tasks outperformed the learners who were instructed by means of unfocused audioappended reading tasks. The results of the current study can be helpful for researchers in the field of second language acquisition (SLA), language teachers, and syllabus and task designers.

Keywords: accuracy, focus on form, focused/unfocused audio-appended reading tasks, rendering task, task-based language teaching

Citation: Alavinia, P., Shafaei, A., \& Salimi, A. (2018). The Effects of Focused/Unfocused AudioAppended Reading Tasks on Intermediate Female EFL Learners' Written Accuracy. International Journal of Instruction, 11(2), 203-220. https://doi.org/10.12973/iji.2018.11214a 


\section{INTRODUCTION}

Conscious processes and the role they play in learning of second language (SL) have been among the issues which have drawn the attention of manifold SLA. The performance of SL learners on different tasks can be affected by several factors such as attitude, planning time, generic features of task, noticing and attention to target language forms (Schmidt 1990; Shafaei, 2012). One of the factors which can affect L2 learners' language learning and performance is noticing or the degree of attention they pay to the forms of the target language. According to Mitchell and Myles (2004), the amount of attention that learners pay to form can affect the extent to which second language input produces SL intake, i.e. new language which has been adequately processed to be incorporated into the learners' developing language system. The emphasis on drawing learners' attention to forms implicitly led to the idea of form-focused instruction (FFI) in SLA. As some SLA researchers argue, it is essential to pay special attention to focus on form (FOF) in teaching adult language learners because it facilitates second language (SL) development (Ellis, 2001, 2008, 2012; Ghariblaki \& Poorahmadi, 2017; Long, 1991, 1996; Nassaji, 2007; Rahimpour, Salimi, \& Farrokhi, 2012, Rooholamin, Biria, \& Haghverdi, 2016). As Ellis (2012) puts it, FOF is based upon the claim that second language learning is promoted if the learners are provided with the opportunity to attend to form while they are engaged in meaning-focused language use. Besides, Doughty and Williams (1998) state that FOF is different from other approaches in that it involves language learners shortly and helps pay simultaneous attention to form, meaning, and use. Also, according to Schmidt's (1994) noticing hypothesis, it is stated that noticing is the essential and adequate condition for input to be converted into intake. Later, Schmidt modified noticing hypothesis and offered that higher degree of noticing leads to higher chance of learning. These changes in SLA theories resulted in the proposal of FOF approach to teaching second/foreign languages. De Bot, Lowie, and Verspoor (2005) defined form-focused instruction as "any pedagogical effort used to draw the learners' attention to language form either implicitly or explicitly" (p. 210). They offered that this can involve the direct teaching of language through grammatical rules or reactions to learners' errors through corrective feedback. Besides, they argue that these can be integrated within an instructional approach known as focus on form (Long, 1991) which is mainly meaning-based.

\section{REVIEW OF THE LITERATURE}

\section{Focus on form (FOF)}

As Schmidt (2001) puts it, noticing hypothesis states that "second language acquisition is largely driven by what learners pay attention to and notice in target language input and what they understand the significance of noticed input to be" (p. 5). Besides, as Schmidt (1994, 2010) claims "what learners notice in input is what becomes intake for learning" (p. 20). According to Klein (1986), as second language learners pay attention to the language forms, they notice important features and seek to find a solution to the problem. Schmidt and Frota (1986) explain this process as noticing the gap between the utterances that second language learners produce and the way the same message is communicated under similar social conditions in the target language. As Schmidt and 
Frota (ibid) argue, noticing makes second language learners capable of attending to the mismatches between their interlanguage systems and the target language and finds the pitfalls of their knowledge of the second language. Moreover, Sheen (2003) holds that a main underlying principle of a form-focused approach is that the tasks employed in the classroom must be based on communicative ideas toward tasks. He also states that the treatment is in the form of rapid corrective feedback which makes the minimal interruption in the process of communication (Sheen, 2003). Based on Sheen's argument (2003), there is a shared assumption between FOF and focus on forms (FOFs) approaches. Regarding focus on form approach, Long (1983) points out that "focus on form actually draws learner's attention to linguistic elements, as they arise incidentally in lessons whose overwriting focus is on meaning or communication" (p.456). Furthermore, Swain's (1985) claims on the role of noticing in output hypothesis draw on the ideas proposed by Schmidt (1994) who claims that learners need to notice a form before they can acquire it. Noticing can take place when learners in the process of generating output perceive that they do not know how to express their intended meaning (Schmidt, 1990). Besides, as Mitchell and Myles (2004) maintain the amount of attention that learners pay to form can affect the extent to which second language input results in second language intake, i.e. new language which has been adequately processed to be incorporated into the learners' developing language system.

There have been several studies in the literature on SLA to investigate different aspects of focus on form (Abdolmanafi, 2012; Ellis, 2002; Rahimpour, Salimi, \& Farrokhi, 2012; Salimi, Bonyadi, \& Asghari, 2014; Schmidt, 2010; Spada \& Lightbown, 1993; White, 1991). Furthermore, though a plethora of investigations have been carried out to investigate different aspects of TBLT (Alavinia, Bonyadi, \& Chegini, 2012; Alavinia \& Sadeghi, 2013; Ellis 2003, 2005, 2012; Robinson, 2001; Salimi, Shafaei, \& Kuhi, 2012; Shafaei, 2012; Shafaei, Salimi, \& Talebi, 2013; Tavakoli \& Foster, 2008), few studies have delved into the potential impacts of focused/unfocused reading tasks on L2 learners' written accuracy enhancement. Thus, the current research intends to fill in the gap in this regard.

\section{RESEARCH QUESTIONS AND HYPOTHESES}

The present study was an effort to investigate the following research questions and hypotheses:

$\mathbf{R Q}_{1}$ : Does instruction through focused/unfocused audio-appended reading tasks influence intermediate female learners' written performance in terms of accuracy?

$\mathbf{R Q}_{2}$ : Does instruction through focused/unfocused audio-appended reading tasks have impact on intermediate female learners' written task accuracy in rule-bound and nonrule-bound structures?

$\mathbf{H 0}_{1}$ : Focused/unfocused instruction through audio-appended reading tasks does not have any impact on intermediate female learners' written task accuracy. 
H0 $_{2}$ : Focused/unfocused instruction through audio-appended reading tasks does not have any effect on intermediate female learners' written accuracy in rule-bound and non-rule-bound structures.

\section{METHOD}

\section{Participants of the Study}

The present research study was implemented in Iran National Language Institute, Miandoab Branch. The participants of the present study involved six intact groups (four experimental and two control groups). They were chosen from among the female learners of English who had been studying English as a foreign language (EFL) for about 5 years and their age range was between 16 and 21. EFL, as defined by Richards and Schmidt (2010), refers to "the context in which language learners learn English in a formal classroom setting, with limited or no opportunities for use outside the classroom, in a country in which English does not play an important role in internal communication" (P. 196). The learners chosen for the purpose of the study included ninety students who were assigned to six groups of fifteen. The criterion for the selection of the participants of the present study was their performance on Oxford Proficiency Test (OPT) employed as the proficiency test of this study. Besides, the participants of the current study were of intermediate language proficiency level. It must be noted that the participants of the present study were selected from female learners in order to control the effect of gender as an intervening factor.

\section{Instructional Materials}

The main material employed in treatment phase of this research was Four Corners book by Richards and Bholke (2012) which is one of the commonly used books in language institutes. In addition, the reading texts for the instruction phase of the study were picked form valid reading books. In order to fit the aim of the study, the chosen texts were re-typed and highlighted. The reading sources from which the texts were selected were as follow:

a) Active 3 by Neil J. Anderson (2008)

b) Cause and Effect by Patricia Ackert and Linda Lee (2006)

c) Read This 3 by Alice Savage (2013)

\section{Data Collection Materials}

Regarding the rendering tasks employed as the pre- and post-tests of the current study, two tasks which required the participants to translate them form Persian into English were taken from the study conducted by Ghaedi (2016). These tasks had already been used in this study as the data collection instruments. One of these tasks was used as the pretest and the other was employed as the posttest of the present study. Both pretest and posttest tasks contained some prompts which included some of the difficult words form the text and their English equivalents, so that the learners could use them if they faced any difficulties in the process of performance on the tasks. The pretest and posttest rendering tasks were administered among the participants of all groups. 


\section{Procedure}

Prior to the treatment phase of the study, OPT was employed to homogenize the participants. Then, in line with the objectives of the study and based on the type of the treatments the learners were exposed to through the treatment phase of the study, they were randomly placed into six experimental and control groups, namely focused rulebound, focused non-rule-bound, unfocused rule-bound, unfocused non-rule-bound, rulebound control, and non-rule-bound control. After that, the pretest was administered among all learners involved in the present study so as to measure their grammatical knowledge. The pretest of the study was a guided rendering task which required the participants to translate the given text from Persian into English with the help of the prompts given. It is worth noting that the target structures under the focus of the present study included passive voice (the rule-bound structure) and prepositions (the non-rulebound structure).

The treatment phase of the present study involved the following steps. In focused groups, i.e. focused rule-bound and non-rule-bound groups, the learners received focused reading texts along with their audio files which included highlighted passive voice structures as the rule-bound and preposition as the non-rule-bound grammatical forms under the focus of the study. As the audio file of the text was being played for the learners, they were provided with the texts containing highlighted passive voice and prepositions. After being exposed to the reading texts along with their audio files, the teacher himself read the text to the learners. As he was reading the text to the learners, the teacher made efforts, including intonation changes and repetition of the intended structures, to highlight the target forms (passive voice and prepositions) included in the text to draw their attention to them. Then, the teacher asked some of the learners to read the text out loud for the class. In addition, at the end of each session, the teacher provided the learners with exercises which made them utilize and practice the target forms highlighted in the text. Unlike the focused groups, in unfocused groups (unfocused rule-bound and non-rule-bound groups), the instruction was conducted through using unfocused audio-appended reading texts. The texts used in unfocused groups were the same as the ones employed in the instruction of focused groups; however, the grammatical forms selected for the sake of the study, i.e. passive voice and prepositions, were not highlighted in them. The participants of unfocused groups were instructed through using unfocused texts as they were being exposed to their audio files. After that, the teacher read the text to the class normally and did not make any efforts to emphasize the intended grammatical forms, i.e. passive voice and prepositions. Later, some of the students were picked to read the unfocused text for the class in a normal manner. After finishing the reading of the texts, the participants were provided with post-reading grammatical exercises to check their development in the target structures utilized in the text. After the implementation of the treatment phase, the post-test, i.e. a guided rendering task accompanied with prompts, was administered among the participants. The learners of all groups were provided with the same task which required them to translate a text from Persian into English. However, their performance on the task was measured on the basis of the type of structure they were exposed to during the treatment phase. That is, the performance of the participants of rule-bound groups was 
measured in accordance with their use of the passive voice structure in their translations. However, the performance of non-rule-bound groups was measured on the basis of their use of prepositions in their translations. Finally, the posttest performance of the learners participating in this study was measured and analyzed through using the accuracy measure proposed by Ellis (2012).

\section{FINDINGS}

The comparison of means of accuracy of focused and unfocused rule-bound groups on rendering task pre-test

The following table shows the mean of accuracy of performance of the participants of focused and unfocused rule-bound groups on rendering task pre-test.

Table 1

The comparison of means of accuracy of performance focused and unfocused rulebound groups on rendering task pre-test

\begin{tabular}{lccc}
\hline Focus & $\mathrm{N}$ & Mean & Std. Deviation \\
\hline Focused Rule-bound & 15 & 0.42 & 0.15 \\
\hline Unfocused Rule-Bound & 15 & 0.40 & 0.16 \\
\hline
\end{tabular}

According to the data presented in Table 1, the mean of accuracy of learners of focused rule-bound group (0.42) was slightly higher than the mean of learners of unfocused rulebound group (0.40) on rendering task pretest of the study.

Also, the results of applying Independent samples t-test for the comparison of means of the performances of learners of focused and unfocused rule-bound groups on rendering task pretest are presented in Table 2.

Table 2

Independent samples t-test for means of accuracy of focused and unfocused rule-bound groups on rendering task pre-test

\begin{tabular}{llcccccc}
\hline & $\begin{array}{l}\text { Levene's Test for } \\
\text { Equality of Variances }\end{array}$ & \multicolumn{2}{l}{ T-test Equality of Means } & \\
\hline & $\mathrm{F}$ & Sig. & $\mathrm{t}$ & $\mathrm{df}$ & $\begin{array}{l}\text { Sig (2- } \\
\text { tailed) }\end{array}$ & $\begin{array}{l}\text { Mean } \\
\text { Difference }\end{array}$ & $\begin{array}{l}\text { Std. Error } \\
\text { Difference }\end{array}$ \\
\hline $\begin{array}{l}\text { Equal variances } \\
\text { assumed }\end{array}$ & 0.00 & 0.98 & 0.28 & 28 & 0.78 & 0.01 & 0.05 \\
\hline $\begin{array}{l}\text { Equal variances } \\
\text { not assumed }\end{array}$ & & & 0.28 & 27.88 & 0.78 & 0.01 & 0.05 \\
\hline
\end{tabular}

According to the data provided in Table 2, there was no significant difference between the performances of learners of focused and unfocused rule-bound groups in terms of accuracy on rendering task pretest of the study.

The comparison of means of accuracy of performance of learners of focused and unfocused non-rule-bound groups on rendering task pre-test

Table 3 shows the mean of accuracy of performance of learners of focused and unfocused non-rule-bound groups on rendering task pre-test. 
Table 3

The comparison of means of accuracy of performance focused and unfocused non-rulebound groups on rendering task pre-test

\begin{tabular}{lccc}
\hline Focus & $\mathrm{N}$ & Mean & Std. Deviation \\
\hline Focused Non-Rule-bound & 15 & 0.52 & 0.11 \\
\hline Unfocused Non-Rule-Bound & 15 & 0.53 & 0.14 \\
\hline
\end{tabular}

As the data provided in Table 3 indicates, the mean of accuracy of performance of the participants of focused non-rule-bound group (0.52) was not so much different from the mean of accuracy of learners of unfocused non-rule-bound group (0.53) on rendering task pre-test.

Also, Table 4 indicates the results of applying Independent samples t-test for comparing means of accuracy of performance of learners focused and unfocused non-rule-bound groups on rendering task pre-test.

Table 4

Independent samples t-test for means of accuracy of focused and unfocused non-rulebound groups on rendering task pre-test

\begin{tabular}{llllllll}
\hline \multicolumn{7}{c}{$\begin{array}{l}\text { Levene's Test for } \\
\text { Equality of Variances }\end{array}$} & \multicolumn{2}{l}{ T-test Equality of Means } \\
\hline & $\mathrm{F}$ & Sig. & $\mathrm{t}$ & $\mathrm{df}$ & $\begin{array}{l}\text { Sig (2- } \\
\text { tailed) }\end{array}$ & $\begin{array}{l}\text { Mean } \\
\text { Difference }\end{array}$ & $\begin{array}{l}\text { Std. Error } \\
\text { Difference }\end{array}$ \\
\hline $\begin{array}{l}\text { Equal variances } \\
\text { assumed }\end{array}$ & 1.85 & 0.18 & -0.11 & 28 & 0.91 & -0.00 & 0.04 \\
\hline $\begin{array}{l}\text { Equal variances } \\
\text { not assumed }\end{array}$ & & & -0.11 & 26.13 & 0.91 & -0.00 & 0.04 \\
\hline
\end{tabular}

According to the data presented in Table 4, the results of the Independent samples t-test revealed that there was not a significant difference between accuracy of the performances of the participants of focused and unfocused non-rule-bound groups on rendering task pretest of the study.

The comparison of means of accuracy of performance of focused, unfocused, and control rule-bound groups on rendering task pre-test

In order to compare means of accuracy of focused, unfocused, and control rule-bound groups on rendering task pre-test, One-way ANOVA was applied as the statistical means of analysis. The results of employing One-way ANOVA are presented in the following Table.

Table 5

The results of One-way ANOVA for the comparison of means of accuracy of performance of focused, unfocused, and control rule-bound groups on rendering task pre-test

\begin{tabular}{llllll}
\hline & Sum of Squares & df & Mean Square & F & Sig. \\
\hline Between Groups & 0.00 & 2 & 0.00 & 0.07 & 0.92 \\
\hline Within Groups & 1.17 & 42 & 0.02 & & \\
\hline Total & 1.18 & 44 & & & \\
\hline
\end{tabular}


Based on the data provided in Table 5, there was not a significant difference between accuracy performances of the participants of focused, unfocused, and control non-rulebound groups on rendering task pretest of the study.

Besides, Table 6 shows the results of multiple comparison of LSD Post Hoc test for the comparison of means of accuracy of focused, unfocused, and control rule-bound groups on rendering task pre-test.

Table 6

The results of LSD Post Hoc test for the comparison of means of accuracy of performance of focused, unfocused, and control rule-bound groups on rendering task pre-test

\begin{tabular}{llccccc}
\hline & & $\begin{array}{c}\text { Mean } \\
\text { Difference } \\
(\mathrm{I}) \text { Method }\end{array}$ & $\begin{array}{c}\text { Std. } \\
\text { Error }\end{array}$ & Sig. & $\begin{array}{c}\text { Lower } \\
\text { Bound }\end{array}$ & $\begin{array}{c}\text { Upper } \\
\text { Bound }\end{array}$ \\
\hline $\begin{array}{l}\text { Focused } \\
\begin{array}{l}\text { Rule- } \\
\text { Bound }\end{array}\end{array}$ & $\begin{array}{l}\text { Unfocused } \\
\text { Rule-Bound }\end{array}$ & 0.01 & 0.06 & 0.78 & -0.10 & 0.14 \\
\hline & Control & & & & & 0.14 \\
\hline $\begin{array}{l}\text { Unfocused } \\
\text { Rule- } \\
\text { Bound }\end{array}$ & $\begin{array}{l}\text { Focused Rule- } \\
\text { Bound }\end{array}$ & -0.01 & 0.06 & 0.78 & -0.14 & 0.10 \\
\hline & Control & 0.00 & 0.06 & 0.91 & -0.11 & 0.13 \\
\hline Control & $\begin{array}{l}\text { Focused Rule- } \\
\text { Bound }\end{array}$ & -0.02 & 0.06 & 0.70 & -0.14 & 0.10 \\
\hline & $\begin{array}{l}\text { Unfocused } \\
\text { Rule-Bound }\end{array}$ & -0.00 & 0.06 & 0.91 & -0.13 & 0.11 \\
\hline
\end{tabular}

The data presented in Table 6 are the results of applying LSD Post Hoc test for comparing and finding the differences between means of accuracy of the participants of focused, unfocused, and control rule-bound groups on rendering task pretest of the present study. The results of data analysis showed no significant difference between accuracy mean of the three groups.

The comparison of means of accuracy of performance of focused, unfocused, and control non-rule-bound groups on rendering task pre-test

One-way ANOVA was applied as the statistical means of analysis to compare means of accuracy of focused, unfocused, and control non-rule-bound groups on rendering task pre-test. The results of data analysis are provided in Table 7.

Table 7

The results of One-way ANOVA for the comparison of means of accuracy of performance of focused, unfocused, and control non-rule-bound groups on rendering task pre-test

\begin{tabular}{lccccc}
\hline & Sum of Squares & df & Mean Square & F & Sig. \\
\hline Between Groups & 0.01 & 2 & 0.00 & 0.53 & 0.59 \\
\hline Within Groups & 0.75 & 42 & 0.01 & & \\
\hline Total & 0.77 & 44 & & & \\
\hline
\end{tabular}


According to the data presented in Table 7, there was not a significant difference between the performance of the participants of focused, unfocused, and control nonrule-bound groups in terms of accuracy on rendering task pretest of the study.

Also, Table 8 shows the results of multiple comparison of LSD Post Hoc test for the comparison of means of accuracy of focused, unfocused, and control non-rule-bound groups on rendering task pre-test.

Table 8

The results of LSD Post Hoc test for the comparison of means of accuracy of performance of focused, unfocused, and control non-rule-bound groups on rendering task pre-test

\begin{tabular}{|c|c|c|c|c|c|c|}
\hline & & Mean & & & $\begin{array}{l}95 \% \\
\text { Interval }\end{array}$ & Confidence \\
\hline (I) Method & (J) Method & $\begin{array}{c}\text { Difference } \\
(\mathrm{I}-\mathrm{J})\end{array}$ & $\begin{array}{l}\text { Std. } \\
\text { Error }\end{array}$ & Sig. & $\begin{array}{l}\text { Lower } \\
\text { Bound }\end{array}$ & $\begin{array}{l}\text { Upper } \\
\text { Bound }\end{array}$ \\
\hline \multirow{3}{*}{$\begin{array}{l}\text { Focused } \\
\text { Non-Rule- } \\
\text { Bound } \\
\end{array}$} & Unfocused & -0.00 & 0.04 & 0.91 & -0.10 & 0.09 \\
\hline & $\begin{array}{l}\text { Non-Rule- } \\
\text { Bound }\end{array}$ & & & & & \\
\hline & Control & 0.04 & 0.04 & 0.41 & -0.05 & 0.13 \\
\hline \multirow[t]{2}{*}{$\begin{array}{l}\text { Unfocused } \\
\text { Rule-Bound }\end{array}$} & $\begin{array}{l}\text { Focused Non- } \\
\text { Rule-Bound }\end{array}$ & 0.00 & 0.04 & 0.91 & -0.09 & 0.10 \\
\hline & Control & 0.04 & 0.04 & 0.35 & -0.05 & 0.14 \\
\hline \multirow[t]{2}{*}{ Control } & $\begin{array}{l}\text { Focused Rule- } \\
\text { Bound }\end{array}$ & -0.04 & 0.04 & 0.41 & -0.13 & 0.05 \\
\hline & $\begin{array}{l}\text { Unfocused Non- } \\
\text { Rule-Bound }\end{array}$ & -0.04 & 0.04 & 0.35 & -0.14 & 0.05 \\
\hline
\end{tabular}

The data presented in Table 8 are the results of applying LSD Post Hoc test for finding the differences between means of accuracy of the participants of focused, unfocused, and control non-rule-bound groups on rendering task pretest of the study. The results of data analysis indicated that there was no significant difference between accuracy mean of the three groups.

\section{The comparison of means of accuracy of focused and unfocused rule-bound groups on rendering task post-test}

The following table shows the mean differences of accuracy of performance of the participants of focused and unfocused rule-bound groups on rendering task post-test.

Table 9

The comparison of means of accuracy of performance focused and unfocused rulebound groups on rendering task post-test

\begin{tabular}{lccc}
\hline Focus & $\mathrm{N}$ & Mean & Std. Deviation \\
\hline Focused Rule-bound & 15 & 0.74 & 0.09 \\
\hline Unfocused Rule-Bound & 15 & 0.38 & 0.09 \\
\hline
\end{tabular}

According to the data presented in Table 9, the mean of performance of learners of focused rule-bound group (0.74) was higher than the mean of learners of unfocused rulebound group (0.38) on rendering task posttest of the study. That is, the learners of the 
focused rule-bound group produced had more accuracy in their task performance than the participants of unfocused group on rendering task posttest of the study.

In addition, the results of applying Independent samples t-test for the comparison of means of accuracy of the performances of learners of focused and unfocused rule-bound groups on rendering task posttest are presented in Table 10.

Table 10

Independent samples t-test for means of accuracy of focused and unfocused rule-bound groups on rendering task post-test

\begin{tabular}{lccccccc}
\hline \multicolumn{7}{c}{$\begin{array}{l}\text { Levene's Test for } \\
\text { Equality of Variances }\end{array}$} & \multicolumn{7}{l}{ T-test Equality of Means } & \\
\hline & $\mathrm{F}$ & Sig. & $\mathrm{t}$ & $\mathrm{df}$ & $\begin{array}{l}\text { Sig (2- } \\
\text { tailed) }\end{array}$ & $\begin{array}{l}\text { Mean } \\
\text { Difference }\end{array}$ & $\begin{array}{l}\text { Std. Error } \\
\text { Difference }\end{array}$ \\
\hline $\begin{array}{l}\text { Equal variances } \\
\text { assumed }\end{array}$ & 0.03 & 0.85 & 10.25 & 28 & 0.00 & 0.36 & 0.03 \\
\hline $\begin{array}{l}\text { Equal variances } \\
\text { not assumed }\end{array}$ & & & 10.25 & 27.99 & 0.00 & 0.36 & 0.03 \\
\hline
\end{tabular}

According to the data presented in Table 10, there was a significant difference between the performances of focused and unfocused rule-bound groups in terms of accuracy on rendering task posttest of the study. That is, the participants of focused rule-bound group outperformed the learners of unfocused rule-bound group in terms of accuracy of their performance on rendering task posttest of the study.

The comparison of means of accuracy of performance of learners of focused and unfocused non-rule-bound groups on rendering task post-test

Table 11 shows the mean of accuracy of performance of learners of focused and unfocused non-rule-bound groups on rendering task post-test.

Table 11

The comparison of means of accuracy of performance focused and unfocused non-rulebound groups on rendering task post-test

\begin{tabular}{lccc}
\hline Focus & $\mathrm{N}$ & Mean & Std. Deviation \\
\hline Focused Non-Rule-bound & 15 & 0.66 & 0.08 \\
\hline Unfocused Non-Rule-Bound & 15 & 0.38 & 0.12 \\
\hline
\end{tabular}

As the data provided in Table 11 indicates, the mean of accuracy of performance of the participants of focused non-rule-bound group (0.66) was more than the mean of accuracy of learners of unfocused non-rule-bound group (0.38). This shows that accuracy of performance of the participants of focused non-rule-bound group on rendering task posttest of the study was higher than the learners of unfocused non-rulebound one.

Besides, Table 12 indicates the results of applying Independent samples t-test for comparing means of accuracy of performance the learners focused and unfocused nonrule-bound groups on rendering task post-test. 
Table 12

Independent samples t-test for means of accuracy of focused and unfocused non-rulebound groups on rendering task post-test

\begin{tabular}{|c|c|c|c|c|c|c|c|}
\hline & \multicolumn{2}{|c|}{$\begin{array}{l}\text { Levene's Test for } \\
\text { Equality of Variances }\end{array}$} & \multicolumn{5}{|c|}{ T-test Equality of Means } \\
\hline & $\mathrm{F}$ & Sig. & $\mathrm{t}$ & $\mathrm{df}$ & $\begin{array}{l}\text { Sig (2- } \\
\text { tailed) }\end{array}$ & $\begin{array}{l}\text { Mean } \\
\text { Difference }\end{array}$ & $\begin{array}{l}\text { Std. Error } \\
\text { Difference }\end{array}$ \\
\hline $\begin{array}{l}\text { Equal variances } \\
\text { assumed }\end{array}$ & 1.23 & 0.27 & 7.11 & 28 & 0.00 & 0.27 & 0.03 \\
\hline $\begin{array}{l}\text { Equal variances } \\
\text { not assumed }\end{array}$ & & & 7.11 & 25.06 & 0.00 & 0.27 & 0.03 \\
\hline
\end{tabular}

According to the data presented in Table 12, the results of the Independent samples ttest revealed that there was a significant difference between accuracy of performance of the participants of focused and unfocused non-rule-bound groups on rendering task posttest of the study. That is, the learners of focused non-rule-bound group produced more accurate language than the learners of unfocused non-rule-bound one on rendering task posttest of the current research study.

The comparison of means of accuracy of performance of focused, unfocused, and control rule-bound groups on rendering task post-test

In order to compare means of accuracy of focused, unfocused, and control rule-bound groups on rendering task post-test, One-way ANOVA was applied as the statistical means of analysis. The results of employing One-way ANOVA are presented in the following table.

Table 13

The results of One-way ANOVA for the comparison of means of accuracy of performance of focused, unfocused, and control rule-bound groups on rendering task post-test

\begin{tabular}{lccccc}
\hline & Sum of Squares & df & Mean Square & F & Sig. \\
\hline $\begin{array}{l}\text { Between } \\
\text { Groups }\end{array}$ & 1.66 & 2 & 0.83 & 102.25 & 0.00 \\
\hline $\begin{array}{l}\text { Within } \\
\text { Groups }\end{array}$ & 0.34 & 42 & 0.00 & & \\
\hline Total & 2.01 & 44 & & & \\
\hline
\end{tabular}

Based on the data provided in Table 14, there were significant differences between accuracy of the performances of the participants of focused, unfocused, and control nonrule-bound groups on rendering task posttest of the study.

Besides, Table 14 shows the results of multiple comparison of LSD Post Hoc test for the comparison of means of accuracy of focused, unfocused, and control rule-bound groups on rendering task post-test. 
Table 14

The results of LSD Post Hoc test for the comparison of means of accuracy of performance of focused, unfocused, and control rule-bound groups on rendering task post-test

\begin{tabular}{|c|c|c|c|c|c|c|}
\hline & & Mean & & & $\begin{array}{l}95 \% \\
\text { Interval } \\
\end{array}$ & Confidence \\
\hline (I) Method & (J) Method & $\begin{array}{c}\text { Difference } \\
(\mathrm{I}-\mathrm{J})\end{array}$ & $\begin{array}{l}\text { Std. } \\
\text { Error }\end{array}$ & Sig. & $\begin{array}{l}\text { Lower } \\
\text { Bound }\end{array}$ & $\begin{array}{l}\text { Upper } \\
\text { Bound }\end{array}$ \\
\hline \multirow[t]{2}{*}{ Rule-Bound } & $\begin{array}{l}\text { Unfocused } \\
\text { Rule-Bound }\end{array}$ & $0.36^{*}$ & 0.03 & 0.00 & 0.30 & 0.43 \\
\hline & Control & $0.44 *$ & 0.03 & 0.00 & 0.37 & 0.50 \\
\hline \multirow[t]{2}{*}{ Rule-Bound } & $\begin{array}{l}\text { Focused } \\
\text { Rule-Bound }\end{array}$ & $-0.36^{*}$ & 0.03 & 0.00 & -0.43 & -0.30 \\
\hline & Control & $0.07 *$ & 0.03 & 0.03 & 0.00 & 0.13 \\
\hline \multirow[t]{2}{*}{ Control } & $\begin{array}{l}\text { Focused } \\
\text { Rule-Bound }\end{array}$ & $-0.44^{*}$ & 0.03 & 0.00 & -0.50 & -0.37 \\
\hline & $\begin{array}{l}\text { Unfocused } \\
\text { Rule-Bound }\end{array}$ & $-0.07 *$ & 0.03 & 0.03 & -0.13 & -0.00 \\
\hline
\end{tabular}

The data presented in Table 14 are the results of applying LSD Post Hoc test for finding the differences between means of accuracy of the participants of focused, unfocused, and control rule-bound groups on rendering task posttest of the present study. The results of data analysis showed that there were significant differences between accuracy of the performances of the three groups. According to the table, the learners of focused rule-bound group produced more accurate language than the learners of unfocused and control rule-bound groups on rendering task post-test. Also, it must be noted that the participants of unfocused rule-bound group outperformed the participants of the control rule-bound group in terms of accuracy of their performance on rendering task posttest of this research study.

The comparison of means of accuracy of performance of focused, unfocused, and control non-rule-bound groups on rendering task post-test

One-way ANOVA was applied as the statistical means of analysis to compare means of accuracy of focused, unfocused, and control non-rule-bound groups on rendering task post-test. The results of data analysis are provided in Table 15.

Table 15

The results of One-way ANOVA for the comparison of means of accuracy of performance of focused, unfocused, and control non-rule-bound groups on rendering task post-test

\begin{tabular}{lccccc}
\hline & Sum of Squares & df & Mean Square & F & Sig. \\
\hline Between Groups & 1.01 & 2 & 0.50 & 52.28 & 0.00 \\
\hline Within Groups & 0.40 & 42 & 0.01 & & \\
\hline Total & 1.42 & 44 & & & \\
\hline
\end{tabular}


According to the data presented in Table 15, there was a significant difference between the performance of the participants of focused, unfocused, and control non-rule-bound groups in terms of accuracy in cloze test posttest of the present study.

Also, Table 16 shows the results of multiple comparison of LSD Post Hoc test for the comparison of means of accuracy of focused, unfocused, and control non-rule-bound groups on rendering task post-test.

Table 16

The results of LSD Post Hoc test for the comparison of means of accuracy of performance of focused, unfocused, and control non-rule-bound groups on rendering task post-test

\begin{tabular}{|c|c|c|c|c|c|c|}
\hline & & Mean & & & $\begin{array}{l}95 \% \\
\text { Interval }\end{array}$ & Confidence \\
\hline (I) Method & (J) Method & $\begin{array}{l}\text { Difference } \\
(\mathrm{I}-\mathrm{J})\end{array}$ & $\begin{array}{l}\text { Std. } \\
\text { Error }\end{array}$ & Sig. & $\begin{array}{l}\text { Lower } \\
\text { Bound }\end{array}$ & $\begin{array}{l}\text { Upper } \\
\text { Bound }\end{array}$ \\
\hline \multirow[t]{2}{*}{$\begin{array}{l}\text { Focused Non- } \\
\text { Rule-Bound } \\
\end{array}$} & $\begin{array}{l}\text { Unfocused Non- } \\
\text { Rule-Bound }\end{array}$ & $0.27 *$ & 0.03 & 0.00 & 0.20 & 0.34 \\
\hline & Control & $0.34 *$ & 0.03 & 0.00 & 0.27 & 0.42 \\
\hline \multirow[t]{2}{*}{$\begin{array}{l}\text { Unfocused } \\
\text { Rule-Bound }\end{array}$} & $\begin{array}{l}\text { Focused Non- } \\
\text { Rule-Bound }\end{array}$ & $-0.27 *$ & 0.03 & 0.00 & -0.34 & -0.20 \\
\hline & Control & $0.07 *$ & 0.03 & 0.04 & 0.00 & 0.14 \\
\hline \multirow[t]{2}{*}{ Control } & $\begin{array}{l}\text { Focused Rule- } \\
\text { Bound }\end{array}$ & $-0.34 *$ & 0.03 & 0.00 & -0.42 & -0.27 \\
\hline & $\begin{array}{l}\text { Unfocused Non- } \\
\text { Rule-Bound }\end{array}$ & $-0.07 *$ & 0.03 & 0.04 & -0.14 & -0.00 \\
\hline
\end{tabular}

The data presented in Table 16 are the results of applying LSD Post Hoc test for finding the differences between means of accuracy of the participants of focused, unfocused, and control non-rule-bound groups on rendering task posttest of the study. The results of data analysis indicated that there were significant differences between accuracy of the three groups on rendering task post-test. As the data in the table shows, the participants of focused non-rule-bound group outperformed the learners of unfocused and control non-rule-bound groups in terms of accuracy of their performance on rendering task posttest of the study. In addition, there was a significant difference between accuracy of performance of unfocused and control non-rule-bound groups. The learners of unfocused non-rule-bound group produced more accurate language than the learners of the control group.

\section{DISCUSSION}

In order to examine the impacts of focused and unfocused audio-appended reading tasks on female EFL learners' task performance in terms of the linguistic domain of accuracy, the raw scores of the participants were analyzed using SPSS version 19. The results of data analysis revealed that there were significant differences between the written task accuracy of performance of learners who were exposed to focused audio-appended texts and those who received unfocused audio-appended texts in the treatment phase of the current study in both rule-bound and non-rule-bound structures. According to the findings of the study regarding accuracy of performance of female intermediate learners 
on rendering task employed in this study, the participants who received focused audioappended in the treatment phase of the study outperformed those who were instructed by means of unfocused audio-appended texts in terms of accuracy of their written task performance. That is, the female intermediate EFL learners who were instructed via focused audio-appended texts throughout the treatment phase of the study produced more accurate language than the learners of the unfocused and control group. In accordance with the findings of the study for written task accuracy of the intermediate female learners performing rendering task, it was revealed that there were significant differences in the performance of the participants. Furthermore, with regard to the hypotheses proposed in the current research study, both hypotheses were not supported on the basis of the results of the study.

The current study aimed at investigating the effects of focused and unfocused audioappended reading tasks on intermediate female EFL learners' written task accuracy. The findings of the study indicated significant differences between the performances of the participants of the study in terms of their accuracy on the rendering task. That is, the participants who received instruction by means of focused audio-appended reading tasks outperformed those who were instructed through unfocused audio-appended reading tasks in terms of accuracy of their use of passive voice as the rule-bound structure and prepositions as the non-rule-bound structure. The findings of the present study are in line with those obtained by Abdolmanafi (2012), Rahimpour, Salimi, and Farrokhi (2012), Salimi, Bonyadi, and Asghari (2014), Seyyed Ebrahimi (2015), and Roohalamin, Biria, and Haghverdi (2016).

The results of the present study indicated that focused and unfocused reading tasks affected intermediate female EFL learners' task performance in terms of the production element of accuracy, which can be attributed to the deeper processing involved in formfocused instruction. When learners are exposed to FOF instruction, they get involved with the forms provided for them and try to make sense of them. Such a struggle with the forms provided through FOF instruction helps the learners grasp a good mastery and knowledge of the target language forms. In addition, these findings can be imputed to the ideas of noticing hypothesis proposed by Schmidt (1990). He proposed that noticing is the essential and adequate condition for input to be converted into intake. Also, Schmidt (2001) offered that noticing and noticing-the-gap are two critical processes of SLA. In fact, as Schmidt (ibid) argued, the more learners' attention is drawn to target forms, the more the likelihood of acquiring the intended forms. Therefore, on the basis of these arguments, drawing learners' attention to the forms of the target language can facilitate SLA. In addition, the results of the present research can be attributed to of implicit FOF instruction put forward by Ellis (2012). Ellis (ibid) pointed out that drawing learners' attention to second language structures can promote the process of SLA. In line with the above-mentioned arguments, it can be concluded that the written task performance of the participants of the present research study was affected by the implicit attention-drawing strategies employed in the study and the learners who were exposed to focused reading tasks benefited from the implicit FOF strategies used in the present study and outperformed the other learners. 


\section{Pedagogical Implications}

The results of the current research study can be of use for SLA researchers as they fill part of the gap in the literature on focus on form, especially the issues related to the topic of the study. Also, the results of this research support the positive impacts of FOF instruction, implicit FOF in particular, on language learners' grammatical development. Moreover, syllabus and task designers can find the present study of interest. They can use the results of the present study in designing form-focused reading tasks accompanied by audio files to help second language learners improve their grammatical knowledge. Furthermore, the results of this study can have some uses for language teachers, especially second or foreign language teachers. These teachers can use implicit FOF instruction along with focused and unfocused audio-appended reading tasks to promote their learners' grammatical knowledge.

\section{REFERENCES}

Abdolmanafi, S. J. (2012). Effects of form-focused instruction on the learning of relative clauses. The Journal of Language and Linguistic Studies, 8/1, 192-210.

Ackert, P., \& Lee, L. (2006). Cause and effects. Adult and Academic ESL, Thomson Heinle.

Alavinia, P., Bonyadi, A., \& Chegini, F.M. (2012). On the effect of task-complexitybased instruction of incidental vocabulary on Iranian academic learners' vocabulary learning. International Journal of Applied Linguistics \& English Literature, 1/6, 26-36.

Alavinia, P., \& Sadeghi, T. (2013). The impact of differentiated task-based instruction via heeding learning styles on EFL learners' feasible proficiency gains. $3 L$ : Language, Linguistics, Literature, 19/1, 75-91.

Anderson, J. N. (2008). Active 3.Thomson Heinle, Canada.

De Bot, K., Lowie, W., \& Verspoor, M. (2005) Second Language Acquisition, an advanced resource book. London: Routledge.

Doughty, C., \& Williams, J. (Eds.). (1998). Focus on form in classroom second language acquisition. New York: Cambridge University Press.

Ebrahimi, S. S. (2015). The effect of focus on form on the acquisition of English middle voice by Iranian EFL learners. Theory and Practice in Language Studies, 5/9, 18421849.

Ellis, R. (2001). Investigating form-focused instruction. In R. Ellis (Ed.), Form-focused instruction and second language learning (pp.1-46). Malden, MA: Black well publishers.

Ellis, R. (2002). Does form-focused instruction affect the acquisition of implicit knowledge? A review of the research. Studies in Second Language Acquisition 24, $223-$ 236. 
Ellis, R. (2003). Task-based language learning and teaching. Oxford: Oxford University Press.

Ellis, R. (2005). Planning and task performance in a second language. Amsterdam: John Benjamins.

Ellis, R. (2008). The study of second language acquisition. Oxford: Oxford University Press.

Ellis, R. (2012). Language teaching research and language pedagogy. WileyBlackwell, Sussex.

Foster, P., \& Skehan, P. (1999). The influence of planning and focus of planning on task-based performance. Language Teaching Research, 3, 215-247.

Ghaedi, A. (2016). The differential effects of three output prompting corrective feedback strategies (explicit correction, meta-linguistic feedback and elicitation) on female Iranian EFL learners' uptake with regard to tense, voice and agreement. Unpublished MA Thesis, Urmia University, Urmia, Iran.

Ghariblaki, Z., \& Poorahmadi, M. (2017). The effect of recast vs. Clarification request as two types of corrective feedback on Iranian intermediate EFL learners' structural knowledge. Journal of Language Teaching and Research, 8/1, 87-96.

Klein, E. C. (1995). Second versus third language acquisition: Is there a difference? Language Learning, 45, 419-465.

Long, M.H. (1983). Does second language instruction make a difference? A review of the research. TESOL Quarterly, 17/3, 359-382.

Long, M. H. (1985). A role for instruction in second language acquisition: task-based language teaching. In K. Hyltenstamand M. Pienemann (Eds.), Modelling and assessing second language acquisition (pp.77-99). Clevedon: Multilingual Matters.

Long, M. H., (1991). Focus on form: A design feature in language teaching methodology. In K. de Bot, R. Grinberg, \& C. Kramsch (Eds.), Foreign Language research in crosscultural perspective (pp. 39-52). Amsterdam: John Benjamins.

Long, M. H. (1996). The role of linguistic environment in second language acquisition. In W.C.Ritchie \& T.K.Bhatia (Eds.). Handbook of second language acquisition, (pp.413-463). San Diego: Academic Press.

Long, M. (Ed.) (2007) .Problems in SLA, Mahwah, NJ: Erlbaum.

Mitchel, R., \& Myles, F. (2004). Second Language Learning Theories. Oxford University Press.

Nassaji, H. (2007). Elicitation and reformulation and their relationship with learner repair in dyadic interaction. Language Learning, 57, 511-548.

Rahimpour, M. (2008). Implementation of task-based approaches to language teaching. Pazhuhesh-e-Zabanha-ye Khareji Journal, University of Tehran, 41, 45-61. 
Rahimpour, M. (2010). Current trends on syllabus design in FL instruction. Procedia Social and Behavioral Sciences, 2, 1660-64.

Rahimpour, M., Salimi, A., \& Farrokhi, F. (2012).The effect of intensive and extensive focus on form on EFL learners' written accuracy. Theory and Practice in Language Studies, 2/11, 2277-2283.

Richards, J.C., \& Schmidt, R. (2010). Dictionary of language teaching and applied linguistics. London: Longman.

Robinson, P. (2001). Task complexity, task difficulty, and task production: exploring interactions in a componential framework. Applied Linguistics, 22/1, 27-57.

Rooholamin, A., Biria, R., \& Haghverdi, H. R. (2016). Effectiveness of proactive intensive FFI in cultivating grammatical knowledge of Iranian EFL learners at different proficiency levels. English Language Teaching, 9/3, 197-206.

Salimi, A., Bonyadi, A., \& Asghari, A. (2014). The effect of focus on form on EFL learners' written task accuracy across different proficiency levels. Theory and Practice in Language Studies, 4/4, 829-838.

Salimi, A., Shafaei, A., \& Kuhi, D. (2012). The Impact of the generic features of tasks on L2 learners' written production. Procedia-Social and Behavioral Sciences, 46, 653662.

Savage, A. (2010).Read this 3. Cambridge University Press, Cambridge, USA.

Schmidt, R. (1990). The role of consciousness in second language learning. Applied Linguistics, 11, 129-158.

Schmidt, R. (1994). "Implicit Learning and the cognitive unconscious: of artificial grammars and SLA". In N.C. Ellis (Ed.), Implicit and explicit learning of Languages (pp. 165-209). San Diego, CA: Academic Press.

Schmidt, R. (2001). Attention, In P. Robinson (Ed.), Cognition and second Language instruction (pp. 3-32). Cambridge: Cambridge University Press.

Schmidt, R. (2010). Attention, awareness, and individual differences in language learning. In W. M. Chan, S. Chi, K. N. Cin, J. Istanto, M. Nagami, J. W. Sew, T. Suthiwan, and I. Walker, Proceedings of CLASIC 2010, Singapore, December 2-4 (pp.721-737). Singapore: National University of Singapore, Centre for Language Studies.

Shafaei, A. (2012). The effects of generic features of task on L2 learners' oral task performance in EFL context. Unpublished Master Thesis, Islamic Azad University, Maragheh Branch, Maragheh, Iran

Shafaei, A., Salimi, A., \& Talebi, Z (2013). The impact of gender and strategic pre-task planning time on EFL learners' oral performance in terms of accuracy. Journal of Language Teaching and Research, 4(4), 746-753 
Sheen, Y. (2003). Focus on form-a myth in the making. ELT Journal, 57, 255-233.

Spada, N. (1997). Form-focused instruction and second language acquisition: A review of classroom and laboratory research. Language Teaching, 30, 73-87.

Spada, N., \& Lightbown, P. (1993). Instruction and the development of question in the L2 classroom. Studies in Second Language Acquisition, 15, 205-221.

Tavakoli, P., \& Foster, P. (2008). Task design and second language performance: the effect of narrative type on learner output. Language Learning, 58/2, 439-473.

White, L. (1991). Adverb placement in second language acquisition: Some effects of positive and negative evidence in the classroom. Second Language Research, 7, 133161. 